\title{
Technical justification of the application of double regulation of ground water level (sub- irrigation) in the conditions of the republic of Karakalpakstan
}

\author{
Zakir Turlibaev ${ }^{1 *}$, and Sagit Kurbanbaev ${ }^{2}$ \\ ${ }^{1}$ Karakalpak State University, Nukus, Karakalpakstan, Uzbekistan \\ ${ }^{2}$ Karakalpak braanch oficce of the Scentific-research Institute of irrigation and water problems, \\ Karakalpakstan, Uzbekistan
}

\begin{abstract}
The article contains proposals for double regulation of the groundwater level to obtain a high yield with the lowest water consumption. In the article, all side-by-side studies of the issues of double regulation of the groundwater level and scientifically-based proposals are given on them. The report contains the results of studies carried out at experimental sites in the Khojaili region and Kungrad regions of the Republic of Karakalpakstan. According to the data of the conducted field studies on the collector, the calculated parameters were obtained for double regulation by the construction of retaining structures. During the growing season, the collector was locked, and the optimal soil moisture was achieved and, accordingly, the yield of agricultural crops was increased.
\end{abstract}

\section{Introduction}

In the context of global water scarcity, the rational use of water for irrigating crops is gaining momentum. In this regard, the leading countries in the practice of irrigated agriculture (USA, China, India, Russia, Israel, etc.) use scientifically grounded irrigation systems for crops during a period of water shortage, saving river water and increasing crop yields through the use of low-mineralized water from the collector as an additional source of water [1].

To mitigate the negative consequences in the context of an ever-increasing water shortage in the republic, scientific research on the use of collector waters in areas with low salinity $(3.0 \mathrm{~g} / \mathrm{l})$ for land irrigation is relevant [2-5].

The practice of reclamation science shows that when developing the theoretical foundations of drainage, such conditions are set that the deeper the level of drainage and groundwater, the higher their reclamation efficiency. Based on such a plan, drainage systems were designed in these areas, and their construction was carried out. As a rule, at a low groundwater level (less than $3.0 \mathrm{~m}$ ), the process of secondary soil salinization practically stops [4].

*Corresponding author: zakir_18_89@mail.ru 
Decrease in the groundwater level below the critical value (above $3.0 \mathrm{~m}$ ) guaranteed excludes the occurrence of secondary salinization, but, in turn, leads to an increase in irrigation rates on the one hand and, on the other hand, a negative impact on the development of agricultural crops, especially, this can become the reason for the lack of the necessary moisture for the development of crop yields. In these cases, it becomes necessary to apply the regulation method (sub-irrigation) of double regulation of the groundwater level $[4,6]$.

In the conditions of the arid zone, including the Republic of Karakalpakstan, the level of groundwater occurrence plays an important role in forming the water-salt regime of irrigated lands, i.e., changes in humidity, salt regime, ultimately the level of crop yields.

The practice of amelioration science shows that when developing the theoretical foundations for calculating drainage, conditions were laid down that approve the position; the deeper the drainage and groundwater level, the higher their ameliorative efficiency. In this plan, drainage systems were designed in these territories, and their construction was also carried out.

As a rule, when the groundwater level is deep (below $3 \mathrm{~m}$ ), the process of secondary soil salinization practically stops. On irrigated lands, a semi-automorphic or closer to an automorphic type of soil formation is formed. At the same time, an intensive process of drying out of the upper soil layer occurs, which negatively affects the growth and development of plants. The irrigation regime (for VI, VII, and VIII hydromodular regions) is not calculated for such conditions [2-5].

The lowering of the groundwater level below the critical value, although it guarantees the occurrence of secondary salinization, leads to an increase in the irrigation and irrigation rates of agricultural crops.

Let's analyze the course of changes in the groundwater level over a long-term period. The following can be noted, starting from 1965, simultaneously with the construction of large collectors, the volume of supplied water increased, both in annual volume and per unit area, as a result of which there was a sharp rise in the level of groundwater, in the process of secondary salinization began in the soil-forming process. Despite the huge volume of water supplied, there is no improvement in the land reclamation state.

On the one hand, excessive water withdrawal for irrigation caused a rise in the groundwater level. Due to excess moisture, irrigation and irrigation rates were significantly reduced. On the other hand, this accelerated the process of secondary soil salinization and led to a decrease in crop yields.

By the period 1965 - 70, the groundwater level reached $1.20 \mathrm{~m}$, and the process of secondary soil salinization began. This, in turn, led to a decrease in the yield of cotton, wheat, and other crops.

Starting in 2007, a state program was adopted to improve the ameliorative condition of irrigated lands. During 2007 - 2012, a large amount of work was carried out to reconstruct interdistrict collectors and the on-farm network, as a result of which there was a widespread lowering of the ground level.

The main reasons for the lowering of the groundwater level are, on the one hand, the reconstruction of collectors, and on the other hand, the regional decrease in water availability, which has been taking place in recent years.

As a result of these factors, in recent years, in some places (where there are local slopes), there are questions of lowering the groundwater level below $2.8-3.0 \mathrm{~m}$ from the earth's surface. This, in turn, leads to the drying up of the topsoil and an increase in the number and volume of irrigation and irrigation rates. Such cases are observed (even in high-water years) in some areas with an area of 1.0 - 2.0 thousand hectares (Turkul, Takhtakupyr, Shumanai districts) and in the field, farmers (in years of average water supply 
and dry years) themselves in a primitive way arrange earth bridges, thereby creating backwaters on the collectors.

Currently, the republic pays special attention to the efficient use of water resources, ensuring the safety and reliability of water bodies using various types of energy-saving technologies. In this direction, including to ensure the safety of water bodies, the improvement of the methods of rational use and effective management of water resources are necessary.

\section{Methods}

In the process of research, field and experimental methods, methods of water balance, hydrochemical, and natural-analogue systematic analysis were used. All research work was carried out by hydraulic, hydrometric, and geodetic methods, including the measurement of water flow by the hydrometric method, salinization of water and soil by the laboratory method.

\section{Results and Discussion}

Double regulation of soil moisture creates artificial soil moisture by creating trailers in drainages and collectors in dry years and years of average water supply. The need for additional soil moisture is based on the discrepancy between the amount of incoming water and its consumption for complete evaporation and its entry into the drainage system. Bilateral groundwater table management is used when humidification methods are ineffective. Groundwater level control is used in drying-humidification systems. Their basic diagram differs from simple systems: the collector system serves to dry and simultaneously moisten the soil, controlling groundwater level. Such systems are called two-way control systems, two-way control of the soil water regime[7,10]. The drainage system requires protective equipment to control the groundwater level. Their number depends on the unit area, drainage slope, water level difference before and after the barrier equipment, etc. In the process of moistening, the movement of the soil flow from the reservoir or drainage is not steady, as a result of which the position of the depression curve changes over time. After water supply, after a certain time t, the depression curve reaches a certain height corresponding to a stationary position, at which the direction of movement of the soil flow changes towards the collector. [8,9].To solve this problem, it is possible to determine the stationary position of the depression curve at a given rise in the water horizon in the humidifier by the value $\Delta \mathrm{h} 0$ (Fig. 1)

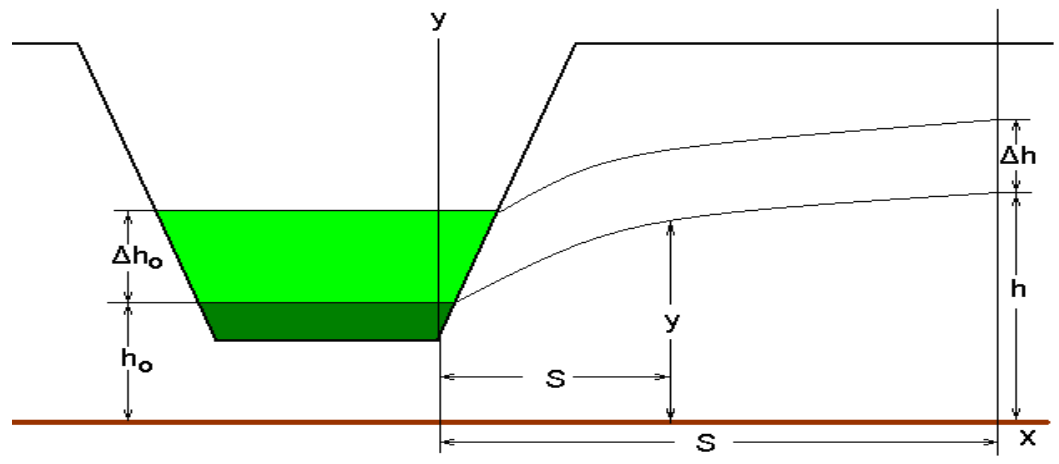

Fig. 1. Calculated scheme of regulation application groundwater level 
In the presence of a collector (or a system of collectors), the equation of the stationary position of the depression curve is:

$$
y^{2}=-\frac{\left(h^{2}-h_{0}^{2}\right) x^{2}}{S^{2}}+2 \frac{\left(h^{2}-h_{0}^{2}\right) x}{S}+h_{0}^{2}
$$

For a single inflow to the collector from one side:

$$
q=k\left[\frac{h^{2}-h_{0}^{2}}{S}-\frac{\left(h^{2}-h_{0}^{2}\right) x}{S^{2}}\right]
$$

$$
\text { at } \mathrm{x}=0 \quad q=\frac{k\left(h^{2}-h_{0}^{2}\right)}{S}
$$

Usually, when the water horizon in a reservoir rises by $\Delta \mathrm{h} 0$, then after stabilization of the depression curve, the position of the groundwater level, in the middle between the collectors, changes by $\Delta \mathrm{h}$, and the value of a single inflow will look like:

$$
q=k\left[\frac{(h-\Delta h)^{2}-\left(h_{0}+\Delta h_{0}\right)^{2}}{S}\right]
$$

When a stationary position of the depression curve occurs, the flow rate of the soil flow will look like this:

$$
\Delta h^{2}+2 h \Delta h-\left(2 h_{0} \Delta h_{0}+\Delta h_{0}^{2}\right)=0
$$

In this case, we obtain the value of $\Delta \mathrm{h}$ :

$$
\Delta h=\sqrt{h^{2}+2 h_{0} \Delta h_{0}+\Delta h_{0}^{2}}-h
$$

To lower the groundwater level in the middle between the collectors after the recession of the water horizon in them, the equation is:

$$
\Delta h=\sqrt{h^{2}+2 h_{0} \Delta h_{0}+\Delta h_{0}^{2}}+h
$$

Suppose the territory has a number of collectors (drains). In that case, formula (a) is used to determine the stabilization time of the groundwater level in the middle between the humidifiers, the stable position of the groundwater level $\Delta \mathrm{h}$ in the middle between the humidifiers and, knowing the distance between them, it is possible to determine the stabilization time $(\mathrm{T})$ groundwater level in the middle between humidifiers:

$$
\phi(\eta)_{\beta}=1-\frac{\Delta h}{\Delta h_{0}} \text { and further } T=\frac{\beta}{k h_{c p}}\left(\frac{s}{2 \eta}\right)^{2}+t_{0}
$$

These calculation formulas can be applied when calculating double regulation of the groundwater level.

Results of field studies were carried out at a pilot site in the Khodjeyli region and in the Kungrad region of the Republic of Karakalpakstan.

1) According to the results obtained in the experimental plot, the norms for planned and actual irrigation of cotton are as follows: 


\begin{tabular}{|l|c|c|c|}
\hline \multicolumn{1}{|c|}{ Indicators } & Number of watering & $\begin{array}{c}\text { Irrigation rate, cub } \\
\text { meter / ha }\end{array}$ & $\begin{array}{c}\text { Difference } \\
\text { (savings cub } \\
\text { meter / ha) }\end{array}$ \\
\hline no gateway & 7 & 5800 & \\
\hline gateway & 4 & 4340 & 1460 \\
\hline gateway & 5 & 4635 & 1165 \\
\hline
\end{tabular}

When using this method, in the collector, using artificial backwater to raise its level, the water saving rate was $1460 \mathrm{cub}$ meters/ha in the first year and 1165 cub meters/ha in the second year.

2) In a short time before the lock, the soil moisture decreased, and after the lock, an increase in the soil moisture in the upper layer was achieved. The results are as follows:

The water availability indicator for 2 years was low compared to 1 year. Thus, despite the work done on sluicing, the optimum level of soil moisture was not achieved and amounted to $72-85 \%$ of the ultimate field moisture capacity. The groundwater level, including the sluice method, provided moisture to the topsoil and increased cotton yields.

The cotton yield indicators obtained in the experimental plots are as follows:

\begin{tabular}{|c|c|c|}
\hline Years & Circumstances & Yield, $\mathrm{t} / \mathrm{ha}$ \\
\hline 1 & Prior to gateway & 1.12 \\
\hline 2 & After lock & 1.91 \\
\hline
\end{tabular}

As shown from the table, the cotton crop was achieved by achieving optimal moisture in the upper soil layer.

\section{Conclusions}

1 It has been established that when applying double regulation of the groundwater level in collectors, the following requirements must be observed:

a) application of this method will affect those on-farm and off-farm, in which the rate of water consumption is 1.0-1.5 meter cube second.

b) it was determined that in areas where there is an intensive process of water exchange between the collector and groundwater, and the difference between the surface area and the water level in the collector should be large;

2 As a result of the conducted research on the method of double regulation, that is, artificially raising the level of groundwater, it was possible to save 1.2-1.4 thousand cub meter/ha of water resources

3 According to the results of the study, it was determined that in the process of subplowing, to prevent the drainage of the collector slopes, the rate of rising of the water level should not exceed 5-8 cm on the layer and 3-5 cm on the layer during decreases

4 Considering the diversity of local conditions in the Republic of Karakalpakstan, it is necessary to revise the design basis of the reservoirs; there is no need to reduce the groundwater level to $3.0 \mathrm{~m}$, as indicated in the projects in technical and economic terms. Instead, to ensure high yields, it was recommended to introduce the concept of "optimal location of the groundwater level. 


\section{References}

2 Volobuev V.R. Promivka I drenaj zasolennikh zemel // v kn."Problemy zasoleniya pochv I vodnikh istochnikov", pp.42-46. Moskva, (1960)

3 Jurabekov I.Kh., Laktaev N.T. Sovershenstvovaniye orositelmnix sistem i melioratsiya zemel Uzbekistana, p- 150, Tashkent (1983)

4 Duxovniy V.A. Vodoxozyaystvenniy kompleks $\mathrm{v}$ zone orosheniya formirovaniye, razviytiye. //M.: Kolos, p-184. (1984)

5 Qurbanbaev E.K. Meliyoratsiya zemel v Karakalpakiy. // J."Selskoe xozyaystvo Uzbekistana", № 6, pp. 6-17 (1970)

6 Qurbanbaev E.К., Ramazanov A., YAkubov Х.И., Nekotorie voprosi melioratsiy zasolennix zemel v nizovyax Amudari. //Monografiya, Nukus, Tashkent, (1978), p.214.

7 Qurbanbaev E. Quyi-Amudaryo suv resurslarini boshqarish, pp. 66-6, Tashkent (2004)

8 Qurbanbaev E.K., Davletiyarov B., Ispolzovanie mineralizovannix vod dlya promivki zemel. // Vestnik Karakalpakskogo filiala AN UzSSR. pp.66-70 ,Nukus- (1990)

9 Legostaev V.M., Konkov B.S. Meliorativnoe rayonirovanie. // Tashkent. (1951)

10 Nerozin A. Solevoy balans i glubina zaleganiya gruntovix vod. // J.Xlopkovodstvo. pp.43-45, Moskva.(1974).

11 Rakhmonov S., Umurzakov U., Rakhmonov K., Bozarov I., Karamatov O. Land use and land cover change in Khorezm, Uzbekistan. E3S Web of Conferences, 227, 01002, (2021)

12 Umurzakov U., Mamatov F., Aldoshin N., Mirzaev B. Exploration of tillage technologies in the Republic of Uzbekistan, IOP Conference Series, Earth and Environmental Science, 614(1), 012168, (2020)

13 Umurzakov U., and Djuraev B. Prediction of prices for agricultural products through markov chain model, International Journal of Psychosocial Rehabilitation, 24(3), pp. 293-303, (2020)

14 Umurzakov U., Mirzaev B., Salahodjaev R., Isaeva A., and Tosheva S. Energy consumption and economic growth: Evidence from post-communist countries. International Journal of Energy Economics and Policy, 10(6), pp. 59-65, (2020)

15 Yakubov X.I. Melioratsiya zasolennix zemel. // Tashkent, Mexnat (1990).

16 Matyakubov B., Begmatov I., Raimova I. and Teplova G. Factors for the efficient use of water distribution facilities. IOP Conf. Ser. Mater. Sci. Eng. 883, 012025 (2020). 